\title{
UPAYA PENINGKATAN HASIL BELAJAR SOSIOLOGI MATERI PERBEDAAN, KESETARAAN, DAN HARMONI SOSIAL MELALUI MEDIA APLIKASI KAHOOT BAGI PESERTA DIDIK KELAS XI IPS 2 SEMESTER I SMA ISLAM HIDAYATULLAH SEMARANG TAHUN PELAJARAN 2020/2021
}

Oleh:

Ria Yuliani ${ }^{1}$

\begin{abstract}
Abstrak
Penelitian ini bertujuan mengetahui upaya peningkatan hasil belajar sosiologi materi perbedaan, kesetaraan, dan harmoni sosial melalui media aplikasi Kahoot. Penelitian ini dilakukan pada kelas XI IPS 2 yang berjumlah 27 peserta didik di SMA Islam Hidayatullah Semarang sejak bulan Oktober sampai bulan November 2020. Jenis penelitian ini termasuk penelitian tindakan kelas. Berdasarkan siklus penelitian tindakan kelas (Arikunto, 2010:16) terdapat beberapa tindakan yaitu perencanaan tindakan, pelaksanaan tindakan, observasi, dan refleksi. Teknik pengumpulan data menggunakan observasi, dan tes hasil belajar. Analisis data menggunakan deskriptif kualitatif dan kuantitatif. Berdasarkan hasil penelitian dari hasil belajar terjadi peningkatan setiap siklusnya. Pada siklus 1 sebesar $0 \%$ (0 peserta didik) mencapai nilai di atas KKM 74 dengan nilai tertinggi 70 dan nilai terendah 20, siklus ke II sebesar $83 \%$ (23 peserta didik) mencapai nilai di atas KKM 74 dengan nilai tertinggi 100 dan nilai terendah 40. Dengan demikian dapat disimpulkan bahwa penggunaan media kahoot! dapat meningkatkan hasil belajar peserta didik kelas XI IPS 2 SMA Islam Hiayatullah Semarang.
\end{abstract}

Kata Kunci: Hasil Belajar, Media Kahoot!, Penelitian Tindakan Kelas, 


\section{PENDAHULUAN}

Nilai hasil belajar adalah salah satu indikator yang bisa digunakan untuk mengukur keberhasilan belajar seseorang. Nilai hasil belajar mencerminkan hasil yang dicapai seseorang dari segi kognitif, afektif, maupun psikomotorik. Dalam proses belajar mengajar, ada banyak yang pencapaian nilai hasil belajar peserta didik, baik yang berasal dari dalam diri peserta didik (internal) maupun dari lingkungan luar (eksternal). Faktor-faktor tersebut mempengaruhi satu sama lain dan merupakan satu kesatuan yang mendasari hasil belajar peserta didik.

Dari semua faktor yang ada, metode pembelajaran yang dipilih seorang pendidik menjadi sumber dan berkait dengan faktor yang lain. Model pembelajaran yang variatif menjadi salah satu upaya pendidik dalam menyampaikan ilmunya kepada pserta didik. Selain model, media pembelajaran merupakan salah satu komponen pembelajaran yang mempunyai peranan penting dalam proses pembelajaran di kelas. Menurut Kustandi dan Sutjipto (Putri, 2019:28) media pembelajaran adalah suatu alat yang dapat membantu proses belajar mengajar dan berfungsi untuk memperjelas makna pesan yang disampaikan. Hal ini sangat membantu guru dalam mengajar dan memudahkan siswa menerima serta memahami pelajaran.

Demi mencapai hasil belajar yang memuaskan dengan pendidikan yang semakin maju dan didukung perkembangan teknologi pada era modern, maka dari itu dengan menggunakan media pembelajaran aplikasi smartphone berbantu game kahoot dapat merubah peserta didik dalam mengevaluasi hasil belajar agar mendapatkan hasil belajar yang memuaskan, dengan adanya education game, daya serap peserta didik lebih tinggi dibandingkan dengan cara kovensional. Education game membantu peserta didik memotivasi siswa untuk belajar, salah satu bentuknya adalah variasi soal yang di aplikasikan dengan permainan.

Berdasarkan pengamatan yang dilakukan di SMA Islam Hidayatullah, diperoleh informasi guru telah menerapkan beberapa model atau media pembelajaran, namun kebanyakan hanya mengunakan metode ceramah, sehingga membuat peserta didik merasa bosan dalam pembelajaran yang dilakukan dan berpegaruh terhadap prestasi belajar peserta didik yang kurang maksimal.

Terbukti pada penilaian tengah semester gasal mata pelajaran Sosiologi kelas XI IPS 2 mendapat nilai rata-rata terendah yaitu 65 dimana hasil tersebut 
tidak memenuhi Kriteria Ketuntasan Minimal (KKM) sekolah yang telah ditetapkan yaitu 74. Dari 27 peserta didik yang di kelas XI IPS 2, peserta didik yang nilainya di bawah KKM mencapai 15 peserta didik dengan perolehan nilai yang terendah yaitu 40 dan yang nilainya mencapai KKM hanya 12 peserta didik. Maka dari itu dibutuhkan alternative untuk mengatasi keadaan kelas tersebut dengan media pembelajaran yang menarik.

Berbagai media pembelajaran yang menarik diciptakan guna menunjang proses pembelajaran dan membuat siswa lebih tertarik khususnya pada pembelajaran Sosiologi. Dewasa ini salah satu jenis media yang marak digunakan dalam lingkungan pendidikan adalah Kahoot!. Kahoot! merupakan media pembelajaran berbasis permainan atau yang biasa dikenal dengan game based learning. Permainan dilakukan secara online dengan cara guru menampilkan permainan tersebut di depan kelas lalu setiap siswa dapat memainkannya dengan gadget yang mereka miliki. Dengan begitu, siswa berpartisipasi secara aktif di kelas sehingga proses pembelajaran menjadi kondusif, interaktif, dan menarik.

Berdasarkan permasalahan yang ada, peneliti menjadikan Kahoot! Sebagai salah satu alternative dari berbagai macam media pembelajaran lainnya. Sehingga hadirnya media pembelajaran Kahoot! Ini diharapkan pembelajaran Sosiologi menjadi lebih menarik dan tidak membosankan serta membuat siswa menjadi lebih aktif di kelas, dan dapat meningkatkan hasil belajar siswa pada mata pelajaran Sosiologi. Berdasarkan uraian tersebut maka peneliti tertarik untuk melakukan penelitian tindakan kelas yang berjudul "Upaya peningkatan hasil belajar sosiologi materi perbedaan, kesetaraan, dan harmoni sosial melalui media aplikasi kahoot bagi peserta didik kelas XI IPS 2 semester I SMA Islam Hidayatullah Semarang Tahun Pelajaran 2020/2021".

\section{METODE PENELITIAN}

Penelitian ini akan dilaksanakan di SMA Islam Hidayatullah Semarang dan subjek penelitian ini adalah peserta didik kelas XI IPS 2 SMA Islam Hidayatullah Semarang tahun pelajaran 2020/2021 dengan jumlah peserta didik 28 peserta didik yang terdiri dari peserta didik putri semua. Waktu yang akan digunakan peneliti dalam melakukan penelitian tindakan kelas adalah pada 
semester gasal tahun ajaran 2020/2021. Metode yang digunakan dalam penelitian ini adalah penelitian tindakan kelas atau Classroom Action Research.

Penelitian tindakan kelas (Classroom Action Research) berarti penelitian tindakan yang dilakukan di dalam kelas dan memiliki tujuan untuk memperbaiki permasalahan yang ada dalam proses pembelajaran. Berdasarkan siklus penelitian tindakan kelas (Arikunto, 2010:16) PTK dimulai dari tahap perencanaan setelah ditemukannya masalah dalam pembelajaran, dilanjutkan dengan pelaksanaan tindakan, pengamatan, dan refleksi.Teknik pengumpulan data menggunakan observasi dan tes hasil belajar. Analisis data menggunakan deskriptif kualitatif dan kuantitatif.

\section{Prosedur Penelitian}

\section{A. Siklus I}

1) Perencanaan

a. Memilih materi pokok yan akan disampaikan. Adapun materi pokok yang dipilih yaitu perbedaan, kesetaraan, dan harmoni sosial.

b. Menyusun RPP untuk siklus I.

c. Menyiapkan soal post test untuk mengamati hasil belajar peserta didik dalam proses pembelajaran.

d. Menyiapkan media dan sarana pendukung yang diperlukan.

2) Pelaksanaan a. Kegiatan Awal

Pada kegiatan awal guru membuka pelajaran dengan memberi salam dan menkondisikan kesiapan peserta didik dalam menerima pelajaran. Guru menyampaikan kompetensi pembelajaran yang akan dicapai.

b. Kegiatan Inti

Pada kegiatan inti peserta didik diminta membuka platform atau LMS iTunesU yang ada di iPad.

Berikut langkah-langkah pembelajaran dengan media Kahoot! Adalah seperti berikut:

(1) Guru masuk pada https://kahoot.com/ dan klik $\log n$ in pada menu di kanan atas, lalu kita akan diarahkan pada halaman lognin.

(2) Setelah berhasil logn in maka akan tampil laman utama dari Kahoot!, lalu klik Kahoots. Menu Kahoots tersebut berisi permainan-permainan yang sudah dibuat.

(3) Setelah itu akan tampil permainanpermainan yang sudah dibuat lalu pilih permainan mana yang ingin dimainkan pada saat pembelajaran dan klikplay.

(4) Terdapat dua pilihan bermain yaitu classic atau team mode. Jika memilih bermain cara classic maka permainan dilakukan secara individu sedangkan jika memilih bermain cara team mode maka permainan dilakukan secara 
berkelompok.

(5) Setelah memilih Classic atau Team Mode, akan muncul nomor PIN yang akan digunakan siswa untuk mengakses Kahoot!.

(6) Kemudian siswa diarahkan untuk mengakses https://kahoot.it/_dan memasukkan PIN serta nama ke dalam permainan. Jika permainan individu maka akan muncul satu nama saja, tetapi jika permainan kelompok maka akan muncul beberapanama.

(7) Pada perangkat siswa hanya akan muncul pilihan jawaban sedangkan pada tampilan laptop guru akan ada tampilan permainan. Pilihan jawaban pada perangkat siswa akan otomatis berganti menyesuaikan dengan waktupermainan.

(8) Setiap satu pertanyaan yang dijawab oleh siswa akan langsung muncul analisis berapa siswa yang menjawab benar dan salah. Lalu di tampilan siswa akan tertulis correct atau incorrect.

(9) Sebelum lanjut pada soal yang lainnya akan ditampilkan nilai sementara masing-masing siswa pada soal yang telah dikerjakan sesuaiperingkat.

(10)Ulangi langkah tersebut hingga soal berakhir. Pada akhir permaian ini akan muncul nama siswa dengan perolehan nilai tertinggi. Nilai ini berdasarkan skor benar dan skor kecepatan dalam menjawab.

\section{c. Kegiatan Akhir}

Setelah kuis Kahoot selesai guru mengajak peserta didik membuat kesimpulan pembelajaran pada pertemuan ini.

3) Pengamatan

Kegiatan ini adalah pengamatan untuk melihat sejauh mana media Kahoot dalam meningkatkan hasil belajar peserta didik dalam materi perbedaan, kesetaraan dan harmoni sosial.

4) Refleksi

Kegiatan refleksi dilakukan dengan cara diskusi antara peneliti dan kolaborator untuk mengevaluasi hasil tindakan yang telah dilaksanakan berdasarkan hasil kuis Kahoot dan dokumentasi. Hasil refleksi digunakan untuk memperbaiki kegiatan pada siklus II jika pada siklus I belum menunjukkan hasil yang optimal.

\section{Siklus II}

1) Perencanaan

Kegiatan perencanaan dalam siklus II ini terdiri dari kegiatan identifikasi masalah yang masih terjadi pada siklus I dan solusi perbaikan apabila ada kekurangan pada siklus I.

2) Pelaksanaan 
Kegiatan ini merupakan kegiatan yang dilakukan untuk memperbaiki kekurangan yang masih terjadi pada siklus I yang menyebabkan belum terjadinya peningkatan yang maksimal dari hasil belajar peserta didik.

3) Pengamatan

Pengamatan yang dilakukan dalam siklus II sama halnya dilakukan pada siklus I yaitu sejauh mana media Kahoot dalam meningkatkan hasil belajar peserta didik pada materi perbedaan, kesetaraan dan harmoni sosial.

4) Refleksi

Refleksi dalam siklus II ini mengulas secara kritis tentang perubahan yang terjadi setelah adanya tindakan dari kegiatan pembelajaran dengan adanya perbaikan dari siklus I yang telah dilaksanakan. Hasil dari siklus II ini diharapkan terjadi peningkatan hasil belajar peserta didik sesuai dengan indikator keberhasilan yang telah ditetapkan.

\section{Indikator Keberhasilan}

Indikator merupakan patokan untuk menentukan keberhasilan suatu kegiatan atau program, dikatakan berhasil apabila mampu mencapai kriteria yang telah ditentukan dan gagal apabila tidak mampu melampaui kriteria yang telah ditentukan. Penelitian tindakan kelas keberhasilannya dapat ditandai dengan pembahasan ke arah perbaikan, baik terkait dengan guru maupun peserta didik.

Adapun indikator keberhasilan keaktifan peserta didik dalam penelitian ini adalah banyaknya peserta didik yang memperoleh kategori keaktifan belajar tinggi adalah $\geq 75 \%$ yang mengacu pada E.Mulyasa (Windasari, 2019:19) bahwa dari segi proses, pembelajaran dikatakan berhasil dan berkualitas apabila seluruh atau setidak tidaknya sebagian besar $75 \%$ peserta didik terlibat secara aktif dalam proses pembelajaran.

\section{Analisis Data Hasil Belajar}

Analisis data untuk hasil belajar dilakukan dengan membandingkan nilai pada setiap siklus dengan Kriteria Ketuntasan Minimal (KKM) yang telah ditetapkan. Peserta didik dikatakan tuntas pada pembelajaran matematika jika hasil pembelajaran memperoleh nilai $\geq 74$. Sedangkan peserta didik dikatakan belum tuntas apabila memperoleh nilai di bawah KKM yaitu nilai < 74 dan suatu kelas dikatakan tuntas belajarnya (ketuntasan klasikal) jika di dalam kelas tersebut terdapat $\geq 85 \%$ peserta didik yang telah tuntas belajarnya.

\section{HASIL}

Penelitian ini dilakukan melalui 4 tahap yaitu perencanaan, pelaksanaan, 
pengamatan, dan refleksi. Pada siklus I sampai siklus II terdiri dari 2 kali pertemuan dengan materi pembelajaran Perbedaan, Kesetaraan dan Harmoni Sosial.

Berikut data hasil penelitian dari pra siklus sampai siklus II

\section{A. Pra Siklus}

Hasil belajar Peserta didik kelas XI

IPS 2 SMA Islam Hidayatullah pada penilaian tengah semester gasal mata pelajaran Sosiologi kelas XI IPS 2 mendapat nilai rata-rata terendah yaitu 65 dimana hasil tersebut tidak memenuhi Kriteria Ketuntasan Minimal (KKM) yaitu 74. Dari 27 peserta didik yang di kelas XI IPS 2, peserta didik yang nilainya di bawah KKM mencapai 15 peserta didik dengan perolehan nilai yang terendah yaitu 40 dan yang nilainya mencapai KKM hanya 12 peserta didik. Maka dari itu dibutuhkan alternative untuk mengatasi keadaan kelas tersebut dengan media pembelajaran yang menarik.

\section{B. Siklus I}

\section{1) Perencanaan Tindakan}

a. Memilih materi pokok yan akan disampaikan. Adapun materi pokok yang dipilih yaitu perbedaan, kesetaraan, dan harmoni sosial.

b. Menyusun RPP untuk siklus I.

c. Menyiapkan soal post test untuk mengamati hasil belajar peserta didik dalam proses pembelajaran.

d. Menyiapkan media dan sarana pendukung yang diperlukan.

\section{2) Deskripsi Pelaksanaan Tindakan}

a. Kegiatan Awal

Pada kegiatan awal guru membuka pelajaran dengan memberi salam dan menkondisikan kesiapan peserta didik dalam menerima pelajaran. Guru menyampaikan kompetensi pembelajaran yang akan dicapai.

b. Kegiatan Inti

Pada kegiatan inti peserta didik diminta membuka platform atau LMS iTunesU yang ada di iPad.

c. Kegiatan Akhir

Setelah kuis Kahoot selesai guru mengajak peserta didik membuat kesimpulan pembelajaran pada pertemuan ini.

3) Observasi Pelaksanaan Tindakan

Rangkuman hasil kuis Kahoot. 
Tabel 4.1 Hasil Belajar Peserta

Didik Siklus I

\begin{tabular}{|c|c|c|c|}
\hline \multicolumn{4}{|c|}{ Hasil Belajar } \\
\hline No. & $\begin{array}{l}\text { Perolehan } \\
\text { Skor }\end{array}$ & Frekuensi & $(\%)$ \\
\hline 1. & $10-20$ & 6 & $22,2 \%$ \\
\hline 2. & $30-40$ & 7 & $25,9 \%$ \\
\hline 3. & $50-60$ & 8 & $29,6 \%$ \\
\hline 4. & $70-80$ & 6 & $22,2 \%$ \\
\hline & & 27 & \\
\hline $\begin{array}{l}\text { Pese } \\
\text { Tunt }\end{array}$ & KKM & $0 \%$ & \\
\hline Nilai & naksimum & 70 & \\
\hline Nilai & ninimum & 20 & \\
\hline
\end{tabular}

Hasil belajar siklus 1 dapat diketahui dari 27 peserta didik, terdapat $22,2 \%$ atau 6 peserta didik dengan perolehan skor 10-20, kemudian 25,9\% atau 7 peserta didik dengan perolehan skor $30-40,29,6 \%$ atau 8 peserta didik dengan perolehan skor 50-60, 22,2\% atau 6 peserta didik dengan perolehan skor 70-80. Dari penilaian yang dilakukan dalam siklus I didapatkan nilai tertinggi adalah 70 dan nilai terendah adalah 20. Sehingga dapat disimpulkan bahwa nilai peserta didik masih di bawah KKM yaitu 74. Berdasarkan data hasil belajar kelas XI IPS 2 SMA Islam Hidayatullah secara keseluruhan atau secara klasikal masih belum mencapai indikator keberhasilan.

\section{4) Refleksi}

a. Peserta didik masih enggan membaca bahan ajar yang sudah di post guru di iTunesU. b. Peserta didik masih kurang aktif dalam merespon pertanyaan yang diajukan guru. Hal ini terlihat dari beberapa pertanyaan yang diajukan oleh guru secara lisan, namun hanya beberapa peserta didik saja yang berani menjawab pertanyaan.

c. Peserta didik masih kurang aktif dalam bertanya dan hanya pasif mendengarkan apa yang dikatakan guru.

d. Untuk hasil belajar peserta didik yang mencapai KKM 74 belum ada. Ini dikarenakan ada beberapa kendala dalam mengerjakan kuis Kahoot yaitu terkait koneksi internet yang tidak stabil sehingga menyebabkan gagalnya menjawab kuis, sehingga beberapa peserta didik hasil skor kuis Kahoot masih jauh dari KKM.

\section{Siklus II}

\section{1) Perencanaan Tindakan}

a. Memilih materi pokok yan akan disampaikan. Adapun materi pokok yang dipilih yaitu perbedaan, kesetaraan, dan harmoni sosial.

b. Menyusun RPP untuk siklus I.

c. Menyiapkan soal post test untuk mengamati hasil belajar peserta didik dalam proses pembelajaran.

d. Menyiapkan media dan sarana pendukung yang diperlukan.

2) Deskripsi Pelaksanaan Tindakan

1) Kegiatan Awal 
Pada kegiatan awal guru membuka pelajaran dengan memberi salam dan menkondisikan kesiapan peserta didik dalam menerima pelajaran.

\section{2) Kegiatan Inti}

Pada kegiatan inti peserta didik diminta membuka platform atau LMS iTunesU yang ada di iPad.

\section{3) Kegiatan Akhir}

Setelah kuis Kahoot selesai guru mengajak peserta didik membuat kesimpulan pembelajaran pada pertemuan ini.

\section{3) Observasi Pelaksanaan Tindakan}

Hasil observasi tentang hasil belajar materi perbedaan, kesetaraan, dan harmoni sosial pada kelas XI IPS 2 melalui media Kahoot yang dilakukan saat proses pembelajaran siklus II dilihat dari hasil nilai mengerjakan kuis Kahoot. Data hasil belajar dari kuis Kahoot dapat dilihat pada tabel berikut:

Tabel 3.2 Hasil Belajar Siklus 2

\begin{tabular}{|l|c|c|c|}
\hline \multicolumn{1}{|c|}{ No. } & $\begin{array}{c}\text { Perolehan } \\
\text { Skor }\end{array}$ & Frekuensi & $\begin{array}{c}\text { Prosentase } \\
(\%)\end{array}$ \\
\hline 1. & $30-40$ & 2 & $7,4 \%$ \\
\hline 2. & $50-60$ & 2 & $7,4 \%$ \\
\hline 3. & $70-80$ & 12 & $44,4 \%$ \\
\hline 4. & $90-100$ & 11 & $40,7 \%$ \\
\hline \multicolumn{2}{|l|}{27} & \\
\hline Peserta Didik Tuntas & 23 & & \\
\hline \multicolumn{2}{|l|}{ Nilai maksimum } & 100 & \\
\hline
\end{tabular}

\begin{tabular}{|l|l|}
\hline Nilai minimum & 40 \\
\hline
\end{tabular}

Hasil belajar peserta didik kelas XI IPS 2 pada siklus II dilihat dari tes hasil belajar peserta didik dapat diketahui dari 27 peserta didik, terdapat $7.4 \%$ atau 2 peserta didik dengan perolehan skor 30-40, kemudian $7.4 \%$ atau 2 peserta didik dengan perolehan skor 50-60, 44,4\% atau 12 peserta didik dengan perolehan skor 70-80, $44,4 \%$ atau 12 peserta didik dengan perolehan skor 70-80. Kemudian 40,7\% atau 11 peserta didik dengan perolehan skor 90-100.

Dari penilaian yang dilakukan terjadi peningkatan dalam siklus II yaitu didapatkan nilai tertinggi 100 dan nilai terendah adalah 40. Sehingga dapat disimpulkan bahwa nilai peserta didik sudah ada yang diatas KKM yaitu sebanyak $23(85 \%)$ peserta didik. Berdasarkan data hasil belajar kelas XI IPS 2 SMA Islam Hidayatullah secara keseluruhan atau secara klasikal sudah mencapai indikator keberhasilan namun belum mencapai titik maksimal.

\section{4) Refleksi}

a) Peserta didik sudah aktif membaca bahan ajar yang sudah di post guru di iTunesU. 
b) Peserta didik sudah aktif dalam merespon pertanyaan yang diajukan guru. Hal ini terlihat dari beberapa pertanyaan yang diajukan oleh guru secara lisan, banyak peserta didik yang berani menjawab pertanyaan.

Hal itu menunjukkan bahwa media aplikasi kahoot mampu meningkatan keaktifan belajar peserta didik. Melihat adanya peningkatan dari hasil belajar yang telah mencapai kriteria keberhasilan, maka penelitian dihentikan.

\section{Analisis Pembahasan}

Penelitian tindakan kelas yang telah dilakukan di kelasXI IPS 2 SMA Islam Hidayatullah menggunakan media aplikasi kahoot terdiri dari 2 siklus yaitu siklus I dan II. Berdasarkan hasil penelitian yang telah dilakukan pada siklus I dan II. dengan menggunakan media aplikasi kahoot menunjukkan adanya peningkatan hasil belajar peserta didik . Hal ini dapat dilihat dari rekapitulasi hasil belajar dan keaktifan peserta didik mata pelajaran sosilogi.

\section{Tabel 4.3 Rekapitulasi Hasil Belajar}

Peserta Didik

\begin{tabular}{|c|c|c|c|c|c|}
\hline \multicolumn{6}{|c|}{ Hasil Belajar } \\
\hline No & Perolehan & Frekuensi & Frekuens & $(\%)$ & $(\%)$ \\
i & Skor & Siklus I & Siklus & Siklus \\
& & & Siklus II & I & II \\
\hline 1. & $10-20$ & 6 & 0 & $22,2 \%$ & $0 \%$ \\
\hline 2. & $30-40$ & 7 & 2 & $25,9 \%$ & $7,4 \%$ \\
\hline 3. & $50-60$ & 8 & 2 & $29,6 \%$ & $7,4 \%$ \\
\hline
\end{tabular}

\begin{tabular}{|l|l|c|c|c|c|}
\hline 4. & $70-80$ & 6 & 12 & $22,2 \%$ & $44,4 \%$ \\
\hline 5. & $90-100$ & 0 & 11 & $0 \%$ & $40,7 \%$ \\
\hline Jumlah & 27 & 27 & $100 \%$ & $100 \%$ \\
\hline $\begin{array}{l}\text { Peserta Didik } \\
\text { Tuntas KKM }\end{array}$ & Siklus I & $0 \%$ & & \\
\hline & Siklus II & $85 \%$ & \\
\hline Nilai Maksimum & Siklus I & 70 \\
\hline & Siklus II & 100 & \\
\hline Nilai Minimum & Siklus I & 20 & \\
\hline & Siklus II & 40 \\
\hline
\end{tabular}

Berdasakan Tabel 4.3 menunjukkan bahwa hasil belajar peserta didik mengalami kenaikan setelah dilakukan tindakan. Tabel tersebut menunjukkan keberhasilan penggunaan media aplikasi kahoot pada peserta didik kelas SMA Islam Hidayatullah Semarang. Pembahasan ketuntasan hasil belajar peserta didik tiap siklus dapat diamati pada gambar berikut.

\section{Gambar 4.1 Gambar Diagram}

\section{Ketuntasan}

\section{Hasil Belajar Peserta Didik}

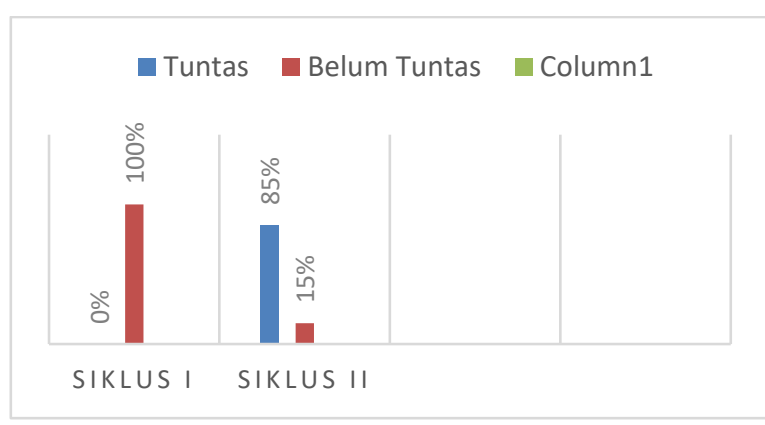

Dari Gambar 4.1 menunjukkan bahwa persentase peserta didik yang tuntas mengalami peningkatan. Pada siklus I persentase peserta didik tuntas sebesar $0 \%$ yaitu 0 peserta didik, pada siklus II mengalami peningkatan menjadi $85 \%$ yaitu 23 
Dari data tersebut ternyata aktivitas dan hasil belajar peserta didik sudah mencapai indikator keberhasilan yang ditetapkan. Sehingga siklus II dipandang sudah cukup, karena dengan penerapan media aplikasi Kahoot dapat meningkatkan hasil belajar sosiologi peserta didik kelas XI IPS 2 SMA Islam Hidayatullah.

\section{DISKUSI}

Kahoot adalah sebuah website di internet yang dapat menghadirkan suasana kuis yang meriah dan heboh ke dalam kelas. Dengan bermain Kahoot ini pembelajaran menjadi sangat menyenangkan dan membuat para peserta didik tidak bosan mengikuti pembelajaran yang sangat sulit dimengerti.

Game-based Learning menjadi salah satu cara memberikan pengalaman pembelajaran yang mampu meningkatkan keikutsertaan kolaborasi peserta didik dalam pembelajaran. Aplikasi Kahoot sebagai platform teknologi pembelajaran mengkombinasikan pengalaman evaluasi pembelajaran dengan mengkombinasikan melalui game interaktif dan dilengkapi sistem monitoring aktifitas para peserta didik Marissa Correia and Raquel Santos (Putri, 2019: 219 ).

Dari penelitian yang telah dilakukan diperoleh peningkatan hasil belajar yang cukup signifikan pada siklus 1 dan 2 . Terbukti dari perolehan nilai tertinggi pada siklus II yaitu 100 dan nilai terendah yaitu 40 dengan persentase ketuntasan peserta didik mencapai 83\% (23 peserta didik) sedangkan pada siklus III terjadi peningkatan dengan perolehan nilai tertinggi yaitu 100 dan nilai terendah 60 dengan persentase ketuntasan sebesar $92 \%$ (25 peserta didik).

Menurut Kurnia Dewi (Puti, 2019 : 219) Inovasi Platfotm Kahoot ini mampu membantu aktifitas evaluasi pembelajaran menjadi menarik, interaktif, kondusif dan mudah dalam memonitaring hasil belajar. Hal ini dapat disimpulkan bahwa penggunaan media Kahoot! dalam proses pembelajaran sangat membantu peserta didik untuk mencapai hasil yang maksimal.

\section{KESIMPULAN}

Berdasarkan hasil pembahasan pada siklus I dan II diperoleh kesimpulan bahwa penggunaan media Kahoot dalam pembelajaran sosiologi dapat meningkatkan hasil belajar peserta didik kelas XI IPS 2 SMA Islam Hidayatullah Semarang dengan ketuntasan hasil belajar siklus I sebesar $0 \%$ ( 0 peserta didik) dengan perolehan nilai 
tertinggi 70 dan nilai terendah 20, menjadi 83\% (23 peserta didik) dengan kemudian meningkat pada siklus II perolehan nilai tertinggi 100 dan nilai presentase ketuntasan hasil belajarnya terendah 40 .

\section{Daftar Pustaka}

Ardianto, Danar. (2018). Peningkatan Keaktifan dan Prestasi belajar Peserta Didik mata pelajaran Instalasi Sistem Operasi dengan Metode Peer Teaching pada Siswa X TKJ SMK N 4 Klaten. Yogyakarta: UNY

Karlina, Senyltiana. (2019). Penggunaan Aplikasi Smartphone Berbantu Game Kahoot untuk Meningkatkan Hasil Belajar Biologi pada Konsep Jaringan Hewan di SMA Pasundan Banjaran. Universitas Pasundan

Purwanto. (2011). Evaluasi Hasil Belajar. Yogyakarta: Pustaka Pelajar.

Putri, Bella Ramadhanty. (2019). Penggunaan Media Kahoot untuk Meningkatkan Hasil Belajar IPS. Jurnal Edukasi IPS Vol.3 No. 2. Jakarta

Putri, Aprilia Riyana. (2019). Implementasi Kahoot Sebagai Media Pembelajaran Berbasis Digital ame Based Learning dalam Menghadapi Era Revolusi Industri 4.0. Universitas Muria Kudus

Stige, Signe Hjelen. (2016). Article:«Kahoot!» as a tool for adjusting teaching to match students' knowledge level and promoting active learning in a lecture setting, Bergen: Department of Clinical Psychology, University of Bergen.

Windasari, Ririn. (2019). Peningkatan Hasil Belajar MatematikaDan Keaktifan Peserta Didik Kelas VII SMP Negeri 8 Salatiga Materi Penyajian Data Melalui Metode $R M E$. IAIN Salatiga 